\title{
Environmental Regulations and Korean Trades ${ }^{\dagger}$
}

\author{
Il Chung Kim* and Mun Seong Choi**
}

ABSTRACT : This paper analyzes the three issues related to the effect of environmental regulations on the Korean trades with gravity equation model: the effect on the Korean exports, the bilateral trade flows between the Korea and the trade partners, and the Korean international competitiveness. For all three issues we carried the empirical tests with fixed effect estimation methods for total industries, non-pollution industries, pollution industries, and also 16 individual pollution industries. We use industry panel data for the 120 largest trading countries with Korea for the years 2000-2010. The Environmental Performance Index (EPI) is used as the proxy variable for the environmental regulation. The empirical result shows that while GDPs of both Korea and its trading partners are very important factors affecting positively the Korean trades for all industries, the environmental regulation of the importing country would be a definite trade barrier to the Korean pollution industries, but not a definite one for the non-pollution industries. In addition, the stricter environmental regulations of Korea's trade partners would weaken the Korean international competitiveness of Korean pollution industries. In this regard, the Porter Hypothesis would have not appeared in the Korean trades of pollution industries during the period observed in this study.

Keywords : Environmental Regulations, Korean Trades, Pollution Industries, Porter Hypothesis

JEL 분류 : Q5

Received: September 4, 2013. Revised: October 1, 2013. Accepted: November 11, 2013.

${ }^{\dagger}$ The earlier version of this paper was presented at the the 3rd Annual Conference of EAAERE held in Huangsan, China in Feb.20-22, 2013.

This research has been carried under the 2012 research grant of Dongguk University.

* Professor, Division of Economics and International Trade, Dongguk University, First and Corresponding author(e-mail: ickim@dongguk.edu)

** Lecturer, Division of Economics and International Trade, Dongguk University, Co-author (e-mail: chmuns@dongguk.edu)

The authors would like to express their appreciation to two unknown referees for their valuable comments. 


\title{
환경규제와 한국의 무역
}

\author{
김일중* · 최문성**
}

요 약 : 본 논문은 중력모형을 이용해서 환경규제가 한국의 수출량, 총무역량 및 국제경쟁력에 어떤 영향을 미치는가를 규명해 보는 것이다. 고정효과 추정방법을 이용해서 전 산업, 비 환경 오염산업, 16 개 환경오염산업을 대상으로 추정하였으며, 자료는 한국과 교역량이 많은 120 개 국가를 선정하여 2000년-2010년 사이의 산업패널자료와 환경성과지수(EPI)를 환경규제의 대 리변수로 사용하였다. 분석 결과 한국과 교역상대국의 국내총생산량이 한국의 무역을 신장시키 는데 큰 영향을 미친 변수라면, 교역상대국의 환경규제는 한국의 오염산업의 수출과 무역량을 감소시키고 국제경쟁력을 떨어뜨리는 무역장벽의 역할을 하는 것으로 나타났다. 그러나 분석기 간 동안 비 오염산업에서는 이러한 환경규제효과가 극명하게 나타나지 않았다. 개별 산업에 대 한 분석 결과 상당한 비중의 오염산업들이 교역상대국의 환경규제에 영향을 받는 것으로 나타 났다. 이런 관점에서 동기간 사이에 한국의 무역에 있어서는 포터가설은 성립하지 않는 것으로 보인다.

주제어 : 환경규제, 한국의 무역, 환경오염산업, 포터가설

접수일(2013년 9월 4일), 수정일(2013년 10월 1일), 게재확정일(2013년 11월 11일)

* 동국대학교 경제통상학부 교수(e-mail: ickim@dongguk.edu)

** 동국대학교 경제통상학부 강사(e-mail: chmuns@dongguk.edu) 


\section{Introduction}

A group of economists as well as policy makers and businessmen have paid attention to the issue of environmental regulation and international competitiveness in both academic and real world. The overall question is: Are the environmental regulations harmful for the international competitiveness of the firms or not? Some insist the stringent environmental regulations seem to be harmful since the more stringent environmental regulations raise the production cost of the firms, resulting in the negative effects on its exports (Brock and Taylor(2005), Copeland and Taylor(2003)). On the other hand, the Porter Hypothesis, initiated by Porter(1991) and Porter and van der Linde (1995), argued that the harmful effect of the environmental regulations would be short run, and a country would become a net exporter potentially due to the positive technological innovation effect induced by more stringent environmental regulations in the long run.1)

There have been extensive empirical studies on the interaction between the environmental regulation and international competitiveness. However, their results vary with the models, data, methodologies used for the analysis. Many of them failed to find the univocal evidence on the subject (Jaffe et al.(1995), (2003), (2005), Palmer et al.(1995), Wally and Whitehead(1994), Cole and Elliott(2003)), while some provided evidences on the Porter Hypothesis with specific industries or firms (Mulatu, Florax and Withagen(2004)).

Among many models used for this issue of environmental regulation effect, the gravity equation model is one of the very popular models used in empirically testing the effect of stringent environmental regulations on the trade flows. A notable study using the gravity model is van Beers and van den Bergh(2003),

1) Pollution haven hypothesis is another view with this issue of environmental regulations and international competitiveness. But it is not directly relevant issue to the purpose of this paper, so that we do not introduce the literature of it here. 
which tests the impact of environmental stringency on bilateral exports. They show OECD countries' exports are negatively and significantly affected by more stringent regulations, whereas those tighter regulations are also reducing imports. Jug and Mirza(2005) also show the export elasticity of relative environmental stringency is negative at 5\% significant level and environmental stringency matters more for Eastern European exporters. Many of these studies, however, failed to find significant evidence of the environmental stringency effect on the trade flows (Grether and Melo(2003), Xu(1999)). One interesting result from these studies is that more empirically significant findings come from the specific industries rather than from the broader sectors or national levels (Albrecht(1998), Murty and Kumar(2003), Harris, Kónya and Mátyás(2002), Constani and Crespi(2008)). Oh and Myung(2005) carry an empirical study on this issue with Korean exports. They show that more stringent environmental regulations of the trade partners have positive effect on the Korean exports due to their negative effect on the price competitiveness using the Environmental Sustainable Index (ESI) as the proxy variable of environmental regulation. This paper, however, was just a cross sectional analysis without time series data since data they used were the ones only for the year 2001. So under the assumption that only the trade partners strengthen the environmental regulation while Korean intensity of environmental regulation stays the same, their study could not take into consideration the long term effect of environmental regulations on the trade flows. Shim and Jeong(2009) tried to test Porter Hypothesis by comparing the effects of environmental regulations of 41 importing countries on technology exports of renewable energy and energy saving industries between Korea and Japan for the years 2001, 2002, and 2005. They used some items of ESI, such as ENCON, innovation and $\mathrm{CO} 2$ damage, as proxy variables of environmental regulation. They proposed their results supported the Porter Hypothesis in the sense that the environmental regulation of the trade partners reduced the exports of both countries to their trade partners. However this 
may not be true since its negative effect on the technology exports to the importing countries would not always mean increase in the exports of regulating countries.

This paper also takes up this issue of the effect of a country's environmental regulations on the international competitiveness and trade flows, with the case between Korea and its trade partners and gravity equation model. We know from GATT Article 3 National Treatment that the environmental regulation of a country would apply to both its domestic firms and the foreign exporting firms, affecting the production costs and thus international competitiveness of both domestic and foreign firms. Its effect would be harmful or beneficial to business firms of both domestic and foreign firms. Following the Porter hypothesis, it would increase the cost of production in the short run and reduce it in the long run through the technological innovation procedure, etc. If it is true, it would weaken the international competitiveness in the short run, and strengthen it in the long run. It may also be inferred that it would reduce the trade flows between two countries in the short run and increase it in the long run. This effect, however, would vary with countries, depending on the relative stringency of their current environmental regulations. If a country's environmental regulation is currently more stringent than its trade partner's, then it would be naturally said that the stricter environmental regulation of the country affects the business firms of the trade partner more than its own domestic firms in terms of costs as well as international competitiveness.

The purpose of this paper is to test three issues related to the effect of environmental regulation --that is, how the trade partner's environmental regulation affects the Korea's exports to it, trade flows between Korea and trade partners, and Korea's relative competitiveness with the trade partner. We test these three issues with three categories of industries--- total industries, non-pollution industries, and pollution industries. In addition, we also test these three issues with 16 individual pollution industries since these industries would be more sensitive to the environmental regulations than other non-pollution industries. In particular, the last 
two issues of the environmental regulation effect on the international competitiveness as well as the trade flows would be related to the Porter Hypothesis.

In section II the gravity equation models adopted are introduced. Three gravity equations will be used for testing three issues considered in this paper. The Section III discusses dataset. The Section IV describes the result of the empirical analyses, and the concluding remarks are followed in Section V.

\section{Model}

The gravity equation model has widely been used for testing the relationship between the environmental regulations and trade flows since Tinbergen (1962) used it for testing the determinants of the international trade. Similar to the functional form of Newton's Law of Universal Gravitation, it is based on the assumption that the trade flows have positive relationship with economy sizes of trade partners and negative relationship with the distances between them. In addition, the model may also include many other determinants characterizing the countries such as the role of trade openness and other policy instruments like environmental regulations.

The typical gravity equation is as follows.

$$
T F_{i j}=\alpha \frac{Y_{i} Y_{j}}{D_{i j}} \cdot Z_{i j}
$$

where $T F_{i j}$ is the amount of the trade flow from country $i$ to country $j, Y_{i}$ is economy size of country $i, Y_{j}$ is economy size of country $\mathrm{j}, D_{i j}$ is the distance between country $i$ and $j, Z_{i j}$ is any other factor(s) affecting trade flows between country $i$ and country $j$.

We modify the equation (1) in three ways to test the three issues discussed in 
the section I. The following formulations of gravity equations are very similar to many other models using the gravity equations related to the environmental stringency, especially for example, Costantini and Crespi(2008).

Equation (2) below is to set up for testing the first issue of trade partner's environmental regulation on Korea's exports. In addition to the factors affecting the trade flows in equation (1), the equation (2) includes some other determinants such as the existence of FTA, environmental regulations and so on, transforming it in the $\log$ terms to facilitate the empirical analysis.

$$
\begin{aligned}
\ln E X_{k i t}= & \beta_{0}+\beta_{1} \ln K G D P_{t}+\beta_{2} \ln G D P_{i t}+\beta_{3} \ln D I S_{k i}+\beta_{4} \ln E P I_{i t} \\
& +\beta_{5} F T A_{k i t}
\end{aligned}
$$

In equation (2), $E X_{k i t}$ is the exports of Korean industries to country $i, K G D P_{t}$ is real gross domestic products of Korea at time $t, G D P_{i t}$ is real gross domestic products of country $i$ at time $t, D I S_{k i}$ is the distance between Korea and country $i$, and $E P I_{i t}$ is the Environmental Performance Index of the country $i$ at time $t$, which is used as the proxy variable of country $i$ 's environmental regulation, assuming that the country $i$ 's environment performance is proportional to its environmental regulation. $F T A_{k i t}$ is the dummy variable of free trade agreement between Korea and country $i$ at time $t$, indicating the economic openness. $E X_{k i t}$, $K G D P_{t}, G D P_{i t}, D I S_{k i}$ and $E P I_{i t}$ take log terms to linearize the original gravity equation, alleviate the heteroskedasticity and the influence caused by the differences of units of variables. The gravity equation generally predicts that Korean exports, $E X_{k i t}$, have positive relationship with the economy size, say $K G D P_{t}$ and $G D P_{i t}$, and economic openness, $F T A_{k i t}$ and negative relationship with distance between two trading countries, $D I S_{k i}$. It can also be predicted that it has negative relationship with the $E P I_{i t}$ of country $i$, which means that the higher the $E P I_{i t}$ 
of country $i$ is, the less the Korean exports to country $i$ is since the higher $E P I_{i t}$ of country $i$ would imply the more stringency of its environmental regulation and so the higher cost of firms of country $i$.

We may modify the equation (2) to be more realistic in the following two ways. First, we take into consideration the fact that Korean exports may vary with the relative stringency between Korean and country $i$ 's environmental regulation. We include the dummy of EPI, EPIDUM, in the equation (2) to examine it. Secondly, it may be interesting to know what relationship the difference in GDP per capita between trade partners would have the trade flows with. So we include the absolute value of difference in GDP per capita between Korea and the country $i, D P G D P_{k i t}$ in equation (2), Equations (3) is the modified one of (2).

$$
\begin{aligned}
\ln E X_{k i t}= & \beta_{0}+\beta_{1} \ln K G D P_{t}+\beta_{2} \ln G D P_{i t}+\beta_{3} \ln D I S_{k i}+\beta_{4} \ln E P I_{i t} \\
& +\beta_{5} E P I D U M_{i t}+\beta_{6} F T A_{k i t}+\beta_{7} \ln D P G D P_{k i t}
\end{aligned}
$$

EPIDUM $_{i t}$ is the dummy variable, which shows the relative stringency of environmental regulations between Korea and country $i$ at time $t$. If the country $i$ 's environmental regulation is more stringent than Korea's, then EPIDUM $M_{i t}$ is one, and zero otherwise. It can be expected that the coefficient $\beta_{5}$ would have a negative value, which implies Korean exports would be smaller for a country of stricter environmental regulation than Korea.

The coefficient of $D P G D P_{k i t}$ would have both positive and negative values. If it is positive, it means that Korean exports become larger for the trade partner with larger income difference. But if it has a negative value, the Korean exports would be larger with the country of similar income, which may support the theory of representative demand and intra-industry trade in the international trade theory.

Environmental regulation of country $i$ virtually affects both exports and imports 
of the country. It means that the environmental regulations of the country would influence the bilateral trade flow(i.e. total trade volume) between the two countries, which is the sum of Korea's exports and imports. So we modify equation (3) using the total trade volume, $T R_{k i t}$ as dependent variable. Then equation (3) becomes equation (4)

$$
\begin{aligned}
\ln T R_{k i t}= & \theta_{0}+\theta_{1} \ln K G D P_{t}+\theta_{2} \ln G D P_{i t}+\theta_{3} \ln D I S_{k i}+\theta_{4} \ln E P I_{i t} \\
& +\theta_{5} E P I D U M_{i t}+\theta_{6} F T A_{k i t}+\theta_{7} \ln D P G D P_{k i t}
\end{aligned}
$$

where $T R_{k i t}$ is total trade volume between Korea and its trade partner $i$ at time $t$.

The third issue we would like to examine is the effect of environmental regulations of Korea and its trade partners on the international competitiveness of Korea. We test this through the equation (5).

$$
\begin{aligned}
\ln \left(E X_{k i t} / I M_{k i t}\right)= & \delta_{0}+\delta_{1} \ln \left(K G D P_{t} / G D P_{i t}\right)+\delta_{2} \ln \left(E P I_{i t} / K E P I_{t}\right) \\
& +\delta_{3} \ln \left(K P G D P_{t} / P G D P_{i t}\right)
\end{aligned}
$$

Here $E X_{k i t} / I M_{k i t}$ is Korea's exports per dollar of imports at time $t$, which stand for the international competitiveness of Korea. If it is larger than one, it can be said that Korea is a net exporter. $K G D P_{t} / G D P_{i t}$ is the Korea's relative GDP to trade partner's at time $t . K E P I_{t}$ is Korean environmental performance index, so that $E P I_{i t} / K E P I_{t}$ means the relative environmental stringency between the trade partner and Korea at time $t$. If $\delta_{2}$ is positive, Korean exports per dollar of imports is meant to increase with a rise in the relative environmental stringency of trade partner's to Korea's, which implies that Korea's international competitiveness relative to trade partners would be strengthened despite the more stringency of trade partner's environmental regulation. $K P G D P_{t}$ is GDP per capita in Korea, 
and $P G D P_{i t}$ is GDP per capita in Korea's trade partner $i$, So $K P G D P_{t} / P G D P_{i t}$ is Korea's relative GDP per capita to trade partner's.

\section{Data}

We include in our analysis 120 largest importing countries from Korea for the years 2000-2010. We select them after eliminating the countries with deficiencies in data. ${ }^{2}$ ) Among them fourteen countries have Free Trade Agreement with Korea.3) Data for Korean exports are extracted from UN Comtrade4), and data for real GDP and GDP per capita of each country from UNCTAD database for the years 2000-2010.5) The distance between two countries is measured in $\mathrm{km}$ between capital cities of two countries, whose data are extracted from CEPII6). This paper focuses on product groups of the pollution industries in Korea, which was classified as pollution industries by Low and Yeats(1992).

The Environmental Performance Index(EPI) is used as the proxy variable for the environmental regulation. This index is produced for evaluating environmental improvement performance of countries, by a team of environmental experts at Yale and Columbia University, in collaboration with the World Economic Forum's(WEF) Center on Global Competitiveness and Performance, and released by WEF every year. EPI is a weighted average of 25 indicators representing 10 policy categories of environmental health and ecosystem vitality.7) The policy categories encompass

2) Those countries encompass the 21 in Asia, 13 in Middle East, 39 in Europe, 3 in North America, 20 in South America, 22 in Africa, 2 in Oceania, etc.

3) They are Brunei, Cambodia, Chile, India, Indonesia, Iceland, Malaysia, Myanmar, Norway, Philippines, Singapore, Switzerland, Thailand, Viet Nam. (Source: Ministry of foreign affairs and trade (http://www.mofat.go.kr))

4) http://comtrade.un.org/

5) UnctadSTAT, http://unctad.org

6) Centered 'Etudes Prospectives et d'Informations internationales

7) It can be found from http://www.weforum.org and Appendix1. 
all the important environmental policy targets such as environmental burden of disease, the effects of air pollution and water quality on the human health and ecosystem, and environment state such as biodiversity and habitat, forestry, fisheries and agriculture, and finally climate change including greenhouse gas emissions. It may be reasonably said that EPI would represent a country's degree of environmental regulation under the following assumptions: Business firms would not internalize the externality they generate without any environmental regulation, and would try to respond minimally to the environmental regulation, although there would be some exceptions. In addition, the pollution abatement activities of business firms would influence the cost of production, and thus production and the trade volumes as well as their competitiveness, regardless of whether business firms take pollution abatement actions voluntarily, or in response to the environmental regulation. In this regard this paper uses the EPI as the proxy of environmental regulation. We use EPI for the years 2000-2010.

\section{Empirical Results}

The most popular methods for considering an unobserved effect of individual country data that affects dependent variable, i.e. the individual heterogeneity, in the estimation of panel data are the fixed effect model and the random effect model. The choosing criterion for more appropriate model out of these two models is related to whether there exist the correlations between the explanatory variables and unobserved effect. The fixed effect model treats this unobserved effect as a fixed unknown parameters, not random variable. In the process of estimating coefficients in the regression model, we can eliminate this unobserved effect through difference or within transformation. Accordingly the consistency of the estimated coefficients is guaranteed in the fixed effect model even in the case that the explanatory variables are correlated with the unobserved effect. On the other hand, the consistent 
estimates can be obtained only with the uncorrelated case between the explanatory variables and the unobserved effect in the random effect model since the model treats the unobserved effect as random variable and assumes the explanatory variables and the unobserved effect are uncorrelated to each other. Accordingly, if the latter assumption is not satisfied, we cannot use the random effect model.

The choice between these two models can be done through the Hausman test. The Hausman test is to test $H_{0}: \operatorname{Cov}\left(X_{k i t}, \alpha_{k j}\right)=0, H_{1}: \operatorname{Cov}\left(X_{k i t}, \alpha_{k j}\right) \neq 0$. Here $X_{k i t}$ is the explanatory variable, $\alpha_{k j}$ is the unobserved effect of individual country data. If we reject the null hypothesis that the unobserved effect of individual country data and the explanatory variable are uncorrelated to each other, we will choose the fixed effect model, and vice versa. The result of the Hausman test shows that the fixed effect model is more appropriate than the random effect

〈Table 1〉 Pollution Industries

\begin{tabular}{|c|c|c|c|}
\hline SITC & Commodity & SITC & Commodity \\
\hline 251 & Pulp and waste paper & 634 & $\begin{array}{l}\text { Veneers, plywood, particle board, and } \\
\text { other wood, works, n.e.s. }\end{array}$ \\
\hline 322 & Briquettes, lignite and peat & 635 & Wood manufactures, n.e.s. \\
\hline 334 & $\begin{array}{l}\text { Petroleum oil and oils obtained from } \\
\text { bituminous minerals(other than crude) }\end{array}$ & 641 & Paper and paperboard \\
\hline 515 & $\begin{array}{l}\text { Organo-inorgano compounds, } \\
\text { heterocyclic compounds, nucleic acids } \\
\text { and their salts, and sulphonamides }\end{array}$ & 642 & $\begin{array}{c}\text { Paper and paperboard, cut to size or } \\
\text { shape, and articles of paper or } \\
\text { paperboard }\end{array}$ \\
\hline 516 & Other organic chemicals & 661 & $\begin{array}{l}\text { Lime, cement, and fabricated } \\
\text { construction materials } \\
\text { (except glass and clay materials) }\end{array}$ \\
\hline 524 & $\begin{array}{c}\text { Other organic chemicals: } \\
\text { organic and inorganic compounds of } \\
\text { precious metals }\end{array}$ & 67 & Iron and steel \\
\hline 525 & Radioactive and associated materials & 68 & Non-ferrous metals \\
\hline 562 & $\begin{array}{l}\text { Fertilizers } \\
\text { (other than those of group 272) }\end{array}$ & 69 & Manufactures of metals, n.e.s. \\
\hline 598 & Miscellaneous chemical product, n. e.s. & & \\
\hline
\end{tabular}

Source : Low and Yeats(1992) 
model since the null hypothesis is rejected with $1 \%$ significance level in our study, so that most of our analyses will be carried with the fixed effect model. As mentioned before, however, we cannot estimate the coefficients of the time-invariant explanatory variables such as distance between two countries with the fixed effect model. So we also tested with the random effect model just for the purpose of examining the distance effect.

We examine Variance Inflation Factor(VIF) through regression analysis among independent variables used in the models to test the multicollinearity problem. The VIFs of most independent variables have the values of a little over one which proves no problem of multicollinearity. ${ }^{8)}$

We now analyze the three issues related to the effect of environmental regulations on the Korean trades: the effect on the Korean exports, the trade flows between the Korea and the trade partners, and the international competitiveness. For all three issues we carried the empirical tests for total industries, non-pollution industries, pollution industries, and also 16 individual pollution industries.9)

\section{The Effect of the Trade Partner's Environmental Regulation on the Korean Exports}

The empirical results for the effect of the trade partner's environmental regulation on the Korean exports are shown in $<$ Table $2>$. All variables except FTA and EPIDUM take the log terms, so that the estimated values of their coefficients can be interpreted as export elasticities of the independent variables.

8) It is known that there is no problem of multicollinearity if VIF is less than 5. The VIF of three variables--EPI, EPIDUM, and KPGDP/PGDP, are little over the 2, which does not also show multicollinearity problem.

9) We exclude SITC 322 Briquettes, lignite and peat from our analysis since data for this industry are not available sufficiently for the analysis. 
〈Table 2〉 The Effects on the Korean Exports

\begin{tabular}{|c|c|c|c|c|c|c|}
\hline \multirow{2}{*}{ Variable } & \multicolumn{2}{|c|}{ Total Industries } & \multicolumn{2}{|c|}{ Non-pollution Industries } & \multicolumn{2}{|c|}{ Pollution Industries } \\
\hline & Fixed & Random & Fixed & Random & Fixed & Random \\
\hline $\mathrm{C}$ & $\begin{array}{c}-22.736^{* * *} \\
(-11.485) \\
\end{array}$ & $\begin{array}{c}-18.754 * * * \\
(-8.682) \\
\end{array}$ & $\begin{array}{c}-19.696^{* * *} \\
(-9.708) \\
\end{array}$ & $\begin{array}{c}-14.071^{* * *} \\
(-6.113) \\
\end{array}$ & $\begin{array}{c}-44.206^{* * *} \\
(-13.038) \\
\end{array}$ & $\begin{array}{c}-41.159 * * * \\
(-12.114)\end{array}$ \\
\hline $\ln ($ KGDP $)$ & $\begin{array}{c}1.732 * * * \\
(8.327) \\
\end{array}$ & $\begin{array}{c}2.545^{* * *} \\
(19.141) \\
\end{array}$ & $\begin{array}{c}1.501 * * * \\
(7.043) \\
\end{array}$ & $\begin{array}{r}2.216^{* * *} \\
(16.264) \\
\end{array}$ & $\begin{array}{c}4.012 * * * \\
(11.265) \\
\end{array}$ & $\begin{array}{c}4.301 * * * \\
(19.536)\end{array}$ \\
\hline $\ln (\mathrm{GDP})$ & $\begin{array}{l}1.732 * * * \\
(12.399)\end{array}$ & $\begin{array}{l}1.018 * * * \\
(21.739)\end{array}$ & $\begin{array}{l}1.751^{* * * *} \\
(12.233)\end{array}$ & $\begin{array}{l}1.036^{* * * *} \\
(20.141)\end{array}$ & $\begin{array}{c}1.764 * * * \\
(7.374)\end{array}$ & $\begin{array}{l}1.201 * * * \\
(17.336)\end{array}$ \\
\hline $\ln (\mathrm{DIS})$ & & $\begin{array}{c}-0.714 * * * \\
(-4.073) \\
\end{array}$ & & $\begin{array}{c}-0.593 * * * \\
(-3.035) \\
\end{array}$ & & $\begin{array}{c}-1.032 * * * \\
(-4.052)\end{array}$ \\
\hline $\ln (\mathrm{EPI})$ & $\begin{array}{c}-0.754 \\
(-1.123) \\
\end{array}$ & $\begin{array}{l}-0.774 * \\
(-1.899) \\
\end{array}$ & $\begin{array}{c}-0.778 \\
(-1.131) \\
\end{array}$ & $\begin{array}{c}-0.856^{* *} \\
(-1.971) \\
\end{array}$ & $\begin{array}{c}-4.348 * * * \\
(-3.783) \\
\end{array}$ & $\begin{array}{c}-1.876^{* * *} \\
(-2.980) \\
\end{array}$ \\
\hline EPIDUM & $\begin{array}{c}-0.067 \\
(-0.923) \\
\end{array}$ & $\begin{array}{c}-0.075 \\
(-1.063) \\
\end{array}$ & $\begin{array}{c}-0.040 \\
(-0.533) \\
\end{array}$ & $\begin{array}{l}-0.136^{*} \\
(-1.929)\end{array}$ & $\begin{array}{c}-0.010 \\
(-0.080)\end{array}$ & $\begin{array}{c}-0.085 \\
(-0.711)\end{array}$ \\
\hline FTA & $\begin{array}{c}-0.095 \\
(-1.033) \\
\end{array}$ & $\begin{array}{c}-0.059 \\
(-0.645) \\
\end{array}$ & $\begin{array}{l}-0.173^{*} \\
(-1.829) \\
\end{array}$ & $\begin{array}{c}0.003 \\
(0.034) \\
\end{array}$ & $\begin{array}{c}0.124 \\
(0.783) \\
\end{array}$ & $\begin{array}{c}0.191 \\
(1.222) \\
\end{array}$ \\
\hline $\ln (\mathrm{DPGDP})$ & $\begin{array}{c}0.278^{* * *} \\
(4.099)\end{array}$ & $\begin{array}{c}0.200^{* * *} \\
(3.308)\end{array}$ & $\begin{array}{c}0.263 * * * \\
(3.784)\end{array}$ & $\begin{array}{c}0.126^{* *} \\
(2.048)\end{array}$ & $\begin{array}{c}0.413 * * * \\
(3.557)\end{array}$ & $\begin{array}{c}0.285^{* * * *} \\
(2.859)\end{array}$ \\
\hline Observation & 1320 & 1320 & 1320 & 1320 & 1320 & 1320 \\
\hline Pairs & 120 & 120 & 120 & 120 & 120 & 120 \\
\hline Adj $R^{2}$ & 0.952 & 0.580 & 0.948 & 0.538 & 0.919 & 0.513 \\
\hline
\end{tabular}

( ) t-value, ${ }^{*} \mathrm{P}<0.1, * * \mathrm{p}<0.05, * * * \mathrm{p}<0.01$

For all three categories of industries considered, GDPs of both Korea and trade partners have positive relationships with Korea's exports, as expected, which is statistically significant at the $1 \%$ level of significance. While the effects of Korea's and its trade partners' GDP on Korea's exports look to be similar for both total industries and non-pollution industries, the Korea's GDP has a larger effect on the exports of Korean pollution industries than the GDP of the trade partners.

The differences in GDP per capita between Korea and trade partners have positive relationships with Korean exports for all three categories of total industries, all of which are statistically significant at the $1 \%$ level of significance. So it may 
be said from these results that the Korea's exports would be larger for the trade partners with greater income differences although their magnitudes are not so big.

EPI of a trade partner has negative relationship with Korean exports for all three categories of total industries. However the negative relationships between trade partner's EPI and Korean exports are statistically significant only for pollution industries, not for total industries and non-pollution industries. This implies that more stringent environmental regulation of the importing country would be a trade barrier to the Korea's exports, especially for the Korean pollution industries. This result would be reinforced with the negative coefficient of EPIDUM. This, however, would not be robust except for the pollution industries since it is statistically significant only for pollution industries.

We have also tested this model for 16 individual pollution industries. It can be seen from $<$ Table A3. 1 $>$ that EPIs of the trading partners have negative relationships with Korean exports for 13 industries. But statistical significances of the relationships are shown only for 6 industries among them---Pulp and Waste Paper(SITC 251), Radioactive and Associated Materials(SITC 525), Miscellaneous Chemical Product (SITC 598), Veneers, Plywood, Particle Board, and Other Wood, Works(SITC 634), Iron and Steel(SITC 67), and Manufactures of Metals(SITC 69). These six industries look to be vulnerable to environmental stringency. The result also shows that the more stringent environmental regulation of the trade partners would increase Korean exports of 3 industries such as Petroleum Oil and Oils obtained from Bituminous Minerals(other than crude)(SITC 334), Other Organic Chemicals (SITC 516), and Wood Manufactures(SITC 635). But we cannot say for sure these positive relationships for these industries since they are not statistically significant.

These results are quite different from Oh and Myung(2005), which shows the positive relationship between a country's environmental regulation and Korean exports for the total industries with statistical significance. They argue that the trade partner's stringent environmental regulation would reduce the productivity of their 
domestic industries, resulting in an increase in Korean exports to the country. This fact occurred in 13 out of 16 pollution industries as well as in total industries.

FTA did not play an important role with affecting the Korean exports during the periods observed since the coefficients of FTA for all three cases of total industries are very small without statistical significance.

As mentioned before, we cannot include one of the important variables in the gravity model but time-invariant variable, the distance between Korea and a trading partner in fixed effect model. So we tried to test it with random effect model. The result shows that distances have negative relationship with Korean exports for all three categories of industries with statistically significance, as expected.

\section{The Effect of the Trade Partner's Environmental Regulations on the Bilateral Trade Flows between Korea and Trade Partners}

The empirical results for the effect of the environmental regulation on the bilateral trade flows(i.e. total trade volume) between Korea and its trade partners are shown in $\langle$ Table $3>$.

GDPs of both Korea and trade partners have positive relationships with bilateral trade flows between Korea and its trade partners for all three categories of industries considered, which is statistically significant at the $1 \%$ level of significance. Like their effects on the Korea's exports, the effects of Korea's and its trade partners' GDPs on their bilateral trade flows also turn out to be similar for both total industries and non-pollution industries. On the other hand, the Korea's GDP has a very larger effect on the bilateral trade flows of the pollution industries than the GDPs of the trade partners as the former case of export effect.

The differences in GDP per capita between Korea and trade partners have also positive relationships with bilateral trade flows between them for all three categories of total industries with small coefficient value, all of which are 
$\langle$ Table 3〉 The effects on the Bilateral Trade Flows

\begin{tabular}{c|c|c|c|c|c|c}
\hline \multirow{2}{*}{ Variable } & \multicolumn{2}{|c|}{ Total Industries } & \multicolumn{2}{c|}{ Non-pollution Industries } & \multicolumn{2}{c}{ Pollution Industries } \\
\cline { 2 - 7 } & Fixed & Random & Fixed & Random & Fixed & Random \\
\hline \multirow{2}{*}{$\mathrm{C}$} & $-21.243^{* * *}$ & $-17.048^{* * *}$ & $-17.835^{* * *}$ & $-14.071^{* * *}$ & $-39.346^{* * *}$ & $-34.318^{* * *}$ \\
& $(-10.717)$ & $(-7.548)$ & $(-9.008)$ & $(-6.113)$ & $(-11.705)$ & $(-10.334)$ \\
\hline \multirow{2}{*}{$\ln ($ KGDP) } & $1.966^{* * *}$ & $2.387 * * *$ & $1.777^{* * *}$ & $2.216^{* * *}$ & $3.255^{* * *}$ & $3.445^{* * *}$ \\
& $(9.441)$ & $(17.636)$ & $(8.542)$ & $(16.264)$ & $(9.217)$ & $(15.876)$ \\
\hline \multirow{2}{*}{$\ln (\mathrm{GDP})$} & $1.410^{* * *}$ & $1.035^{* * *}$ & $1.435^{* * *}$ & $1.036^{* * *}$ & $1.651^{* * *}$ & $1.271^{* * *}$ \\
& $(10.079)$ & $(20.685)$ & $(10.269)$ & $(20.141)$ & $(6.961)$ & $(19.015)$ \\
\hline \multirow{2}{*}{$\ln (\mathrm{DIS})$} & & $-0.626^{* * *}$ & & $-0.593^{* * *}$ & & $-1.031^{* * *}$ \\
& & $(-3.309)$ & & $(-3.035)$ & & $(-4.205)$ \\
\hline \multirow{2}{*}{$\ln (\mathrm{EPI})$} & -0.751 & -0.670 & -0.952 & $-0.856^{* *}$ & $-2.604^{* *}$ & -0.850 \\
& $(-1.117)$ & $(-1.569)$ & $(-1.419)$ & $(-1.971)$ & $(-2.285)$ & $(-1.389)$ \\
\hline \multirow{2}{*}{ EPIDUM } & $-0.278^{* * *}$ & $-0.265^{* * *}$ & $-0.144^{* *}$ & $-0.136^{*}$ & $-0.306^{* *}$ & $-0.353^{* * *}$ \\
& $(-3.826)$ & $(-3.748)$ & $(-1.989)$ & $(-1.929)$ & $(-2.488)$ & $(-2.990)$ \\
\hline \multirow{2}{*}{ FTA } & -0.042 & -0.008 & -0.029 & 0.003 & 0.040 & 0.111 \\
& $(-0.456)$ & $(-0.084)$ & $(-0.314)$ & $(0.034)$ & $(0.255)$ & $(0.719)$ \\
\hline \multirow{2}{*}{$\ln (\mathrm{DPGDP})$} & $0.226 * * *$ & $0.171^{* * *}$ & $0.171^{* *}$ & $0.126^{* *}$ & $0.492^{* * *}$ & $0.380^{* * * *}$ \\
& $(3.325)$ & $(2.789)$ & $(2.519)$ & $(2.048)$ & $(4.272)$ & $(3.883)$ \\
\hline Observation & 1320 & 1320 & 1320 & 1320 & 1320 & 1320 \\
\hline Pairs & 120 & 120 & 120 & 120 & 120 & 120 \\
\hline Adj R ${ }^{2}$ & 0.955 & 0.569 & 0.955 & 0.538 & 0.925 & 0.498 \\
\hline
\end{tabular}

( ) t-value, * $\mathrm{P}<0.1, * * \mathrm{p}<0.05, * * * \mathrm{p}<0.01$

statistically significant. So these results would imply that the Korean trades be smaller for the trade partners with similar incomes although the GDP difference does not look to be a strong factor affecting the Korean trades.

EPI of a Korea's trade partner has negative relationship with Korea's trade volume with the country for all three categories of industries. As is in the export effect, however, the negative relationships between trade partner's EPI and the trade volume are statistically significant only for pollution industries, not for total industries and non-pollution industries. This implies that the environmental stringency of a Korea's trade partner reduces Korean trade volume with it, especially of the pollution industries. This result would be reinforced for the countries with stricter 
environmental regulation, as we can notice from the negative coefficient of EPIDUM. This negative relationship with Korean trades, unlike the former case of export effect, is statistically significant for all three categories of industries.

$<$ Table A3. $2>$ shows the empirical results for the 16 individual pollution industries. The environmental regulations of the trading partners have negative effects on Korean trades for 11 industries, and positive for 5 industries. But none with the positive effects is statistically significant and 5 industries with the negative effects are statistically significant. The industries with statistical significances are Pulp and Waste Paper(SITC 251), Other Organic Chemicals: Organic and Inorganic Compounds of Precious Metals(SITC 524), Radioactive and Associated Materials (SITC 525), Miscellaneous Chemical Product(SITC 598), and Manufactures of Metals(SITC 69). On the other hand, EPIDUM has a negative relationship with Korean trades for 5 industries and positive one for 11 industries. Only Non-ferrous Metals(SITC 68) among the former is statistically significant, and 4 industries out of the latter 11 industries are statistically significant. They are Other Organic Chemicals(SITC 516), Radioactive and Associated Materials(SITC 525), Paper and Paperboard(SITC 641), and Manufactures of Metals(SITC 69). It is notable that while the relationships of EPI and EPIDUM with trade volume are opposite to each other for the industries--Radioactive and Associated Materials(SITC 525) and Manufactures of Metals(SITC 69), both relationships are positive for Other Organic Chemicals(SITC 516) and Paper and Paperboard(SITC 641). So we can not say for sure whether the environmental stringency has negative or positive effect on Korean trades for the former two industries.

These results imply that Porter Hypothesis does not seem to appear in Korean trades, except two pollution industries--Other Organic Chemicals(SITC 516) and Paper and Paperboard(SITC 641). As we saw, the environmental stringency has negative effect on Korean trades in all categories of total industries. And no individual industry with positive effect shows statistical significance. This would be 
the evidence of rejecting Porter Hypothesis in most of the industries in Korea. However it may be said with some reservation that the Porter Hypothesis may occur in Other Organic Chemicals (SITC 516) and Paper and Paperboard(SITC 641), in which both relationship of EPI and EPIDUM with Korean trades are positive although the former one is not statistically significant.

FTA was not also an important factor affecting the Korean trades for the observed periods like its effect on the Korean exports discussed before. Among the 14 FTA countries with Korea, 10 countries with about $70 \%$ trade volume to the total trade volume began FTA with Korea since 2009, and 3 countries with about $25 \%$ trade volume to the total trade volume since 2006 . Taking into consideration the economic downturn and thus a decline in the trade volume of Korea in 2009, the result must be natural. This result would be changed in the future.

As we did for the case of the environmental effect on the Korean exports, we tried to test time-invariant variable, distance, with random effect model. The result shows that distances have negative relationship with Korean trades for all three categories of industries with statistical significance, although the effect was not so large.

\section{The Effect of the Trade Partner's Environmental Regulation on the Korean International Competitiveness}

The third issue we tested with the equation (5) is the effect of environmental regulations of both Korea and its trade partners on the international competitiveness of Korea. The empirical results for the effect are shown in $<$ Table $4>$.

We use the ratio of Korean exports to Korean imports as an index of the Korean international competitiveness, which means Korea's exports per dollar of imports. The Korea's relative GDP to trade partner's(KGDP/GDP) is shown to have a negative relationship with Korea's exports/imports for total industries and a positive 
relationship for pollution industries without statistical significance, and negative relationship for non-pollution industries with 5\% level of significance. And also the Korea's relative GDP per capita to the trade partner's one(KPGDP/PGDP) has negative relationship with Korea's exports/imports for three categories of industries, but without statistical significance. And the coefficients of both KGDP/GDP and KPGDP/PGDP are all very small for all three categories of industries. This may imply that Korea's relative GDP as well as GDP per capita to the trade partner's ones are not the important factors affecting Korea's international competitiveness.

〈Table 4〉 The Effects on the Korean International Competitiveness (Export/Import)

\begin{tabular}{|c|c|c|c|c|c|c|}
\hline \multirow{2}{*}{ Variable } & \multicolumn{2}{|c|}{ Total Industries } & \multicolumn{2}{|c|}{ Non-pollution Industries } & \multicolumn{2}{|c|}{ Pollution Industries } \\
\hline & Fixed & Random & Fixed & Random & Fixed & Random \\
\hline $\mathrm{C}$ & $\begin{array}{c}3.930 * * * \\
(4.387)\end{array}$ & $\begin{array}{c}0.325 \\
(1.286)\end{array}$ & $\begin{array}{c}5.530 * * * \\
(5.878)\end{array}$ & $\begin{array}{l}0.533 * * \\
(2.049)\end{array}$ & $\begin{array}{c}1.039 \\
(0.580)\end{array}$ & $\begin{array}{c}-0.380 \\
(-1.014)\end{array}$ \\
\hline $\ln (\mathrm{KGDP} / \mathrm{GDP})$ & $\begin{array}{c}-0.739 \\
(-1.469)\end{array}$ & $\begin{array}{c}0.150 \\
(1.538)\end{array}$ & $\begin{array}{c}-1.167^{* *} \\
(-2.208)\end{array}$ & $\begin{array}{c}0.149 \\
(1.481)\end{array}$ & $\begin{array}{c}0.136 \\
(0.131)\end{array}$ & $\begin{array}{c}0.435 * * * \\
(3.007)\end{array}$ \\
\hline $\ln (\mathrm{EPI} / \mathrm{KEPI})$ & $\begin{array}{c}3.044 * * * \\
(2.632)\end{array}$ & $\begin{array}{l}1.392 * * \\
(2.002)\end{array}$ & $\begin{array}{c}2.559 * * \\
(2.107)\end{array}$ & $\begin{array}{c}0.750 \\
(1.040)\end{array}$ & $\begin{array}{c}-6.075^{* *} \\
(-2.535)\end{array}$ & $\begin{array}{l}-1.307 \\
(-1.142)\end{array}$ \\
\hline $\begin{array}{c}\ln (\text { KPGDP/PGD } \\
\mathrm{P})\end{array}$ & $\begin{array}{c}-0.455 \\
(-0.905)\end{array}$ & $\begin{array}{c}0.279 * * \\
(2.295)\end{array}$ & $\begin{array}{c}-0.639 \\
(-1.210)\end{array}$ & $\begin{array}{c}0.247^{* *} \\
(1.964)\end{array}$ & $\begin{array}{c}-0.454 \\
(-0.433)\end{array}$ & $\begin{array}{l}0.370 * * \\
(2.001)\end{array}$ \\
\hline Obervations & 1318 & 1318 & 1318 & 1318 & 1214 & 1214 \\
\hline Country Pairs & 120 & 120 & 120 & 120 & 120 & 120 \\
\hline Adj $R^{2}$ & 0.711 & 0.012 & 0.753 & 0.009 & 0.629 & 0.039 \\
\hline $\begin{array}{c}\text { Hausman Test } \\
\chi^{2}(3)\end{array}$ & \multicolumn{2}{|c|}{$34.379 * * *$} & \multicolumn{2}{|c|}{$55.203^{* * *}$} & \multicolumn{2}{|c|}{$8.489^{* *}$} \\
\hline
\end{tabular}

( ) t-value, ${ }^{*} \mathrm{P}<0.1, * * \mathrm{p}<0.05, * * * \mathrm{p}<0.01$

The relative environmental stringencies of the trade partners to Korea are shown to have positive relationships with Korea's international competitiveness index, exports/imports, for total industries and non-pollution industries, and negative relationship with it for pollution industries, all with $5 \%$ or $1 \%$ significance levels. 
The former result implies that the stricter environmental regulations of Korea's trade partners increase the international competitiveness of the non-pollution industries as well as total industries of Korea. This, however, does not seem to support the Porter Hypothesis, taking into consideration the environmental stringency effect on Korean trade volume. Rather, it seems to imply that the stringent environmental regulations of trade partners would weaken the competitiveness of their domestic firms more than the Korean exporting non-pollution firms. The latter result would be more obvious in the sense that the relative environmental stringency of the trade partners to Korea would reduce the international competitiveness of Korean pollution industries.

It is also found from $<$ Table A3. $3>$ that the stricter environmental regulation of the trade partners weaken the international competitiveness of all Korean pollution industries except two industries--Wood Manufactures(SITC 635) and Manufactures of Metals(SITC 69) ${ }^{10}$ ). But this result is statistically significant only for 6 industries --Organo-inorgano Compounds, Heterocyclic Compounds, Nucleic Acids and Teir Salts, and Sulphonamides(SITC515), Other Organic Chemicals(SITC516), Radioactive and Associated Materials(SITC 525), Miscellaneous Chemical Product(SITC 598), Lime, Cement, and Fabricated Construction Materials(except Glass and Clay Materials) (SITC 661), Iron and Steel(SITC 665). It would be said that these industries are very vulnerable to environmental stringency of importing countries.

\section{Concluding Remarks}

This paper has discussed the issue of the effect of a country's environmental regulations on the international competitiveness and trade flows, with the case between Korea and its trade partners and gravity equation model. This issue is

10) The positive relationship between EPI/KEPI and EX/IM are not statistically significant for these two exceptional industries. 
directly or indirectly related to the controversial Porter Hypothesis insisting the positive relationship between the environmental regulation and trade flows.

This paper tried to examine three issues related to the effect of environmental regulation--that is, how the trade partner's environmental regulation affects the Korea's exports to it, trade flows between Korea and trade partners, and Korea's relative competitiveness with the trade partner. We tested these three issues with three categories of industries--total industries, non-pollution industries, and pollution industries, and 16 individual pollution industries.

We used three gravity equations modified for our purpose and fixed effect model for most of our analyses. We used industry panel data for the 120 largest trading countries with Korea for the years 2000-2010. The Environmental Performance Index(EPI) is used as the proxy variable for the environmental regulation.

Important findings are the following.

First, GDPs of both Korea and its trading partners are very important factors affecting positively the Korean exports and total trades for all industries including both pollution and non-pollution industries. And the Korean exports as well as total trade volume would be larger for the trade partners with greater income differences although their magnitudes are not so big. In addition, FTA did not play an important role with affecting the Korean trades.

Second, both the relative GDP and GDP per capita of Korea to its trade partner were not also influential factors to Korean international competitiveness for most industries.

Third, the environmental regulation of the importing country are shown to be a definite trade barrier to the exports of the Korean pollution industries, but not definite one for the other non-pollution industries. The similar results are shown for the effect on the total trade volume between Kora and its trading partners. That is the negative relationships between trade partner's EPI and the trade volume are statistically significant only for pollution industries. 
Fourth, the stricter environmental regulations of Korea's trade partners would reduce the international competitiveness of Korean pollution industries and would increase the international competitiveness of the Korean non-pollution industries. This, however, does not seem to support the Porter Hypothesis, but rather, the stricter environmental regulations of trade partners would weaken the competitiveness of their domestic firms more than the Korean exporting nonpollution firms.

The effects of the environmental regulations on the individual pollution industries would vary with their characteristics and situations in terms of cost, market and environmental regulation, etc. But one thing we can say definitely from this study is that the environmental regulations would affect considerable portion of pollution industries negatively for the international competitiveness. In this regard the Porter Hypothesis would have not appeared in the Korean trade flows of pollution industries, except a few pollution industries, during the period observed in this study.

\section{[References]}

1. Albrecht, J., Environmental costs and competitiveness: A Product-Specific Test of the Porter Hypothesis, University of Ghent, Belgium. Working Paper NO. 50, 1998.

2. Brock, W.A., Taylor, M.S., "Economic Growth and the Environment: a Review of Theory and Empirics," In: Aghion, P., Durlauf, S. (Eds.), Handbook of Economic Growth, vol. 1. Elsevier, pp. 1749 1821. ed. 1, Ch. 28, 2005.

3. Cole, Matthew A. and Robert J. R. Elliott, "Do Environmental Regulations Influence Trade Patterns? Testing Old and New Trade Theories," The World Economy, Vol. 26(8), 2003, pp. 1163 1186 .

4. Copeland, B. R. and M. S. Taylor, Trade and the Environment: Theory and Evidence. Princeton University Press, U.S.A., 2003.

5. Costantini, Valeria and Francesco Crespi, "Environmental Regulation and the Export Dynamics of Energy Technologies,” Ecological Economics, Vol. 66, 2008, pp. 447 460 . 
6. Grether, Jean-Marie and Jaime de Melo, Globalization and Dirty Industries: Do pollution Havens Matter? (London: Centre for Economic Policy Research), 2003.

7. Harris, Mark N., Laszlo Kónya and Laszlo Mátyás, "Modelling the Impact of Environmental Regulations on Bilateral Trade Flows: OECD, 1990-1996," World Economics, Vol. 25(3), 2002, pp. 387 405.

8. Jaffe, Adam B, Steven R. Peterson, Paul R. Portney and Robert N. Stavins, Environmental Regulation and the Competitiveness of U.S. Manufacturing: What Does the Evidence Tell Us?," Journal of Economic Literature, Vol. 33(1), 1995, pp. $132 \sim 163$.

9. Jeffe, Adam B, R. G. Newell and R. N. Stavins, "Technological Change and the Environment,” In: Mäler, K.G. and J. R. Vincent (Eds.), Handbook of Environmental Economics, Vol. 1. Elsevier, pp. 461 516, ed. 1, chapter11, 2003.

10. Jeffe, Adam B, R. G. Newell and R. N. Stavins, "A Tale of Two Market Failures: Technology and Environmental Policy," Ecological Economics, Vol. 54, 2005, pp. $164 \sim 174$.

11. Jug, Jerneja and Daniel Mirza, "Environmental Regulations in Gravity Equations : Evidence from Europe," The world economy, Vol. 28(11), 2005, pp. 1591 1615 .

12. Low, Patrick and Alexander Yeats, "Do Dirty Industries Migrate?," International Trade and the Environment, ed. Patrick Low(Washington D.C: World Bank), 1992, pp. $89 \sim 104$.

13. Mulatu, Abay, Raymond J. G. M. Florax and Cees Withagen, "Environmental Regulation and International Trade: Empirical Results for the Manufacturing Industry in Germany, the Netherlands and the US, 1972 1992," Tinbergen Institute Discussion Paper, TI2004-020/3, 2004,

14. Murty, M. N. and S. Kumar, "Win-win Opportunities and Environmental Regulation: Testing of Porter Hypothesis for Indian Manufacturing Industries," Journal of Environmental Management, Vol. 67(2), 2003, pp. 139 144.

15. Oh, Keun-Yeop and Chang-Yeon Myung, "An Empirical Study of the Relation between Environmental Regulation and Export of Korea," Environmental and Resource Economics Review, Vol. 14(3), 2005, pp. 627 653.

16. Palmer, K., W. E. Oates and P. R. Portney, P. R., "Tightening Environmental 
Standards: the Benefit-cost or the No-cost Paradigm?," Journal of Economic Perspectives, Vol. 9(4), 1995, pp. 119 132.

17. Porter, Michael E., “America's Green Strategy," Scientific American, April 1991, p.168.

18. Porter, Michael E. and Claas van der Linde, "Toward a New Conception of the Environment-Competitiveness Relationship," The Journal of Economic Perspectives, Vol. 9(4), 1995, pp. 97 118 .

19. Shim, Kieun, and Kyounghwa Jeong, "The Impact of Environmental Regulation on the Korea and Japan's Exports of Renewable Energy and Energy Saving Industry,” Environmental and Resource Economics Review, Vol. 18(1), 2009, pp. 75 103.

20. Tinbergen, J., Shaping the World Economy, NewYork: The Twentieth Century Fund, 1962.

21. Van Beers, C. and J. C. J. M. van den Bergh, "Environmental Regulation Impacts on International Trade: Aggregate and Sectoral Analyses with a Bilateral Trade Flow Model," International Journal of Global Environmental Issues, Vol. 3(1), 2003, pp. $14 \sim 29$.

22. Walley, N. and B. Whitehead, "It's not easy being green," Harvard Business Review, Vol. 72(3), 1994, pp. 46 52.

23. Xu, Xinpeng, "Do Stringent Environmental Regulations Reduce the International Competitiveness of Environmentally Sensitive Goods? A Global Perspective," World Development, Vol. 27(7), 1999, pp. 1215 1226.

CEPII, http://www.cepii.fr/anglaisgraph/bdd/distances.htm

EPI, http://epi.yale.edu/

Ministry of foreign affairs and trade, http://www.mofat.go.kr

UNcomtrade, http://comtrade.un.org

UnctadSTAT, http://unctadstat.unctad.org

WEF, http://www.weforum.org 


\section{〈Appendix 1〉Components of Environmental Performance Index}

\begin{tabular}{|c|c|c|}
\hline $\begin{array}{c}\text { Objectives } \\
\text { (weights: \% of EPI) }\end{array}$ & $\begin{array}{l}\text { Policy Categories } \\
\text { (weights: \% of EPI) }\end{array}$ & Indicators \\
\hline \multirow{5}{*}{$\begin{array}{l}\text { Environmental } \\
\text { Health }(50)\end{array}$} & $\begin{array}{l}\text { Environmental } \\
\text { burden of disease (25) }\end{array}$ & Environmental burden of disease \\
\hline & \multirow{2}{*}{$\begin{array}{l}\text { Air pollution: effects } \\
\text { on humans }(12.5)\end{array}$} & Indoor air pollution \\
\hline & & Outdoor air pollution \\
\hline & \multirow{2}{*}{$\begin{array}{l}\text { Water: effects on } \\
\text { humans }(12.5)\end{array}$} & Access to water \\
\hline & & Access to sanitation \\
\hline \multirow{20}{*}{$\begin{array}{l}\text { Ecosystem } \\
\text { Vitality (50) }\end{array}$} & \multirow{4}{*}{$\begin{array}{l}\text { Air Pollution: effects } \\
\text { on ecosystem }(4.2)\end{array}$} & $\begin{array}{c}\text { Sulfur dioxide emissions per populated land } \\
\text { area }\end{array}$ \\
\hline & & $\begin{array}{l}\text { Nitrogen oxides emissions per } \\
\text { populated land area } \\
\end{array}$ \\
\hline & & $\begin{array}{l}\text { Non-methane volatile organic compound } \\
\text { emissions per populated land area }\end{array}$ \\
\hline & & Ecosystem ozone \\
\hline & \multirow{3}{*}{$\begin{array}{l}\text { Water: effects on } \\
\text { ecosystem }(4.2)\end{array}$} & Water quality index \\
\hline & & Water stress index \\
\hline & & Water scarcity index \\
\hline & \multirow{3}{*}{$\begin{array}{l}\text { Biodiversity \& Habitat } \\
(4.2)\end{array}$} & Biome protection \\
\hline & & Marine protection \\
\hline & & Critical habitat protection \\
\hline & \multirow{2}{*}{ Forestry $(4.2)$} & Growing stock change \\
\hline & & Forest cover change \\
\hline & \multirow{2}{*}{ Fisheries (4.2) } & Marine trophic index \\
\hline & & Trawling intensity \\
\hline & \multirow{3}{*}{ Agriculture (4.2) } & Agricultural water intensity \\
\hline & & Agricultural subsidies \\
\hline & & Pesticide regulation \\
\hline & \multirow{3}{*}{ Climate Change (25) } & $\begin{array}{l}\text { Greenhouse gas emissions per capita } \\
\text { (including land use emissions) }\end{array}$ \\
\hline & & $\mathrm{CO} 2$ emissions per electricity generation \\
\hline & & Industrial greenhouse gas emissions intensity \\
\hline
\end{tabular}




\section{〈Appendix 2〉 EPI by country}

\begin{tabular}{|c|c|c|c|c|c|c|c|c|c|}
\hline Country & 2000 & 2005 & 2010 & $\overline{\mathrm{AVG}}$ & Country & 2000 & 2005 & 2010 & $\mathrm{AVG}$ \\
\hline Switzerland & 76.17 & 77.28 & 76.69 & 77.18 & Côte d'Ivoire & 51.36 & 52.70 & 53.55 & 52.67 \\
\hline Norway & 68.13 & 70.19 & 69.92 & 69.55 & Ethiopia & 51.57 & 53.47 & 52.71 & 52.53 \\
\hline Luxembourg & 68.82 & 68.52 & 69.20 & 68.72 & Dominican Rep. & 50.70 & 52.61 & 52.44 & 52.41 \\
\hline Costa Rica & 65.96 & 69.02 & 69.03 & 68.33 & Myanmar & 50.92 & 52.54 & 52.72 & 52.30 \\
\hline Austria & 67.88 & 67.99 & 68.92 & 68.27 & El Salvador & 50.72 & 52.28 & 52.08 & 51.76 \\
\hline Latvia & 63.80 & 69.81 & 70.37 & 68.07 & Belarus & 49.36 & 51.00 & 53.88 & 51.59 \\
\hline Italy & 63.24 & 68.92 & 68.90 & 67.96 & Paraguay & 48.90 & 52.00 & 52.40 & 51.25 \\
\hline Sweden & 66.36 & 67.32 & 68.82 & 67.34 & Zimbabwe & 49.47 & 50.25 & 52.76 & 50.74 \\
\hline France & 62.30 & 67.92 & 69.00 & 66.90 & Honduras & 49.35 & 49.75 & 52.54 & 50.44 \\
\hline Germany & 66.80 & 66.53 & 66.91 & 66.62 & Saudi Arabia & 50.97 & 50.37 & 49.97 & 50.41 \\
\hline United Kingdom & 61.24 & 68.05 & 68.82 & 66.37 & Benin & 49.65 & 50.48 & 50.38 & 50.24 \\
\hline Iceland & 63.95 & 64.77 & 66.28 & 64.93 & Peru & 46.66 & 51.71 & 50.29 & 50.17 \\
\hline Netherlands & 64.06 & 64.75 & 65.65 & 64.81 & Guatemala & 47.53 & 51.82 & 51.88 & 50.15 \\
\hline Lithuania & 61.89 & 64.79 & 65.50 & 64.11 & Indonesia & 47.48 & 49.76 & 52.29 & 49.97 \\
\hline Slovakia & 60.09 & 64.02 & 66.62 & 63.77 & Viet Nam & 48.39 & 49.63 & 50.64 & 49.69 \\
\hline New Zealand & 59.32 & 61.84 & 66.05 & 63.43 & United Arab Emirates & 43.98 & 50.52 & 50.91 & 49.63 \\
\hline Poland & 62.02 & 62.52 & 63.47 & 63.21 & Kenya & 46.86 & 48.89 & 49.28 & 48.89 \\
\hline Finland & 62.22 & 62.96 & 64.44 & 62.79 & Algeria & 46.81 & 48.96 & 48.56 & 48.45 \\
\hline Czech Rep. & 60.52 & 62.96 & 64.79 & 62.73 & Malta & 47.85 & 47.77 & 48.51 & 47.71 \\
\hline Brunei & 62.16 & 62.76 & 62.49 & 62.55 & Togo & 46.56 & 47.74 & 48.66 & 47.71 \\
\hline Japan & 59.68 & 62.60 & 63.36 & 62.30 & Congo & 46.82 & 48.11 & 47.18 & 47.60 \\
\hline Denmark & 60.88 & 63.01 & 63.61 & 62.24 & Lebanon & 47.37 & 47.83 & 47.35 & 47.40 \\
\hline Croatia & 60.79 & 61.48 & 64.16 & 61.86 & Mozambique & 47.22 & 47.10 & 47.82 & 47.32 \\
\hline Malaysia & 59.70 & 61.90 & 62.51 & 61.54 & Mexico & 43.28 & 47.36 & 49.11 & 46.74 \\
\hline Belgium & 53.26 & 62.38 & 63.02 & 61.18 & Senegal & 46.43 & 45.73 & 46.73 & 46.64 \\
\hline Colombia & 58.32 & 61.88 & 62.33 & 60.89 & Russia & 49.28 & 46.06 & 45.43 & 46.58 \\
\hline Slovenia & 56.55 & 61.24 & 62.25 & 60.31 & Ukraine & 46.68 & 45.61 & 46.31 & 46.50 \\
\hline Ecuador & 58.42 & 58.59 & 60.55 & 58.71 & Kyrgyzstan & 46.15 & 46.68 & 46.33 & 46.50 \\
\hline Greece & 55.80 & 58.80 & 60.04 & 58.32 & Qatar & 46.11 & 46.42 & 46.59 & 46.30 \\
\hline Brazil & 54.54 & 58.42 & 60.90 & 58.04 & Angola & 42.79 & 47.25 & 47.57 & 45.95 \\
\hline Spain & 55.92 & 57.60 & 60.31 & 57.97 & Ghana & 44.98 & 46.65 & 47.50 & 45.66 \\
\hline Nicaragua & 55.46 & 59.06 & 59.23 & 57.95 & Tunisia & 43.60 & 45.82 & 46.66 & 45.59 \\
\hline Uruguay & 56.27 & 58.04 & 57.06 & 57.90 & Trinidad and Tobago & 43.34 & 45.54 & 47.04 & 45.48 \\
\hline Thailand & 54.45 & 57.74 & 59.98 & 57.28 & Romania & 42.01 & 45.30 & 48.34 & 44.98 \\
\hline Canada & 55.64 & 56.94 & 58.41 & 56.98 & Morocco & 42.97 & 44.74 & 45.76 & 44.83 \\
\hline Panama & 56.44 & 57.63 & 57.94 & 56.97 & Fmr Sudan & 43.81 & 43.86 & 46.00 & 44.39 \\
\hline Cyprus & 56.24 & 57.45 & 57.15 & 56.90 & Oman & 43.52 & 44.27 & 44.00 & 43.93 \\
\hline Ireland & 54.42 & 57.02 & 58.69 & 56.83 & Mongolia & 41.77 & 43.68 & 45.37 & 43.76 \\
\hline Australia & 56.33 & 56.40 & 56.61 & 56.73 & Turkey & 40.47 & 43.50 & 44.80 & 43.18 \\
\hline Estonia & 55.62 & 55.96 & 56.09 & 56.17 & Cameroon & 41.85 & 42.75 & 42.97 & 42.88 \\
\hline Georgia & 53.63 & 56.22 & 56.84 & 56.07 & Iran & 40.62 & 42.97 & 42.73 & 42.45 \\
\hline USA & 54.27 & 55.43 & 56.59 & 55.49 & China & 41.24 & 41.92 & 42.24 & 42.14 \\
\hline
\end{tabular}




\begin{tabular}{c|c|c|c|c|c|c|c|c|c}
\hline Country & 2000 & 2005 & 2010 & AVG & Country & 2000 & 2005 & 2010 & AVG \\
\hline Gabon & 49.99 & 56.30 & 57.91 & 55.44 & Syria & 40.68 & 42.18 & 42.75 & 41.94 \\
\hline Hungary & 52.36 & 56.50 & 57.12 & 55.33 & Jordan & 39.73 & 41.15 & 42.16 & 41.00 \\
\hline Singapore & 52.82 & 55.58 & 56.36 & 55.30 & Bangladesh & 38.23 & 40.49 & 42.55 & 40.37 \\
\hline South Korea & 52.15 & 56.04 & 57.20 & 55.20 & Haiti & 39.19 & 40.34 & 41.15 & 40.22 \\
\hline Chile & 53.24 & 55.24 & 55.34 & 54.89 & Azerbaijan & 33.66 & 40.00 & 43.11 & 39.54 \\
\hline Venezuela & 53.41 & 55.22 & 55.62 & 54.77 & Pakistan & 35.25 & 39.28 & 39.56 & 38.67 \\
\hline Israel & 54.07 & 54.95 & 54.64 & 54.59 & Nigeria & 37.34 & 38.52 & 40.14 & 38.63 \\
\hline Bolivia & 54.33 & 54.76 & 54.57 & 54.53 & Bosnia Herzegovina & 37.91 & 38.94 & 36.76 & 38.34 \\
\hline Nepal & 50.86 & 52.80 & 57.97 & 54.49 & Tajikistan & 35.58 & 37.93 & 38.78 & 37.51 \\
\hline Portugal & 51.65 & 52.80 & 57.64 & 54.37 & Eritrea & 34.83 & 37.21 & 38.39 & 36.79 \\
\hline Argentina & 51.73 & 53.83 & 56.48 & 54.33 & Libya & 34.53 & 37.02 & 37.68 & 36.64 \\
\hline Zambia & 53.57 & 51.99 & 55.56 & 54.15 & Kuwait & 37.26 & 36.05 & 35.54 & 36.38 \\
\hline Philippines & 50.39 & 54.60 & 57.40 & 54.07 & India & 35.32 & 35.72 & 36.23 & 35.84 \\
\hline Bulgaria & 48.65 & 54.31 & 56.28 & 53.97 & South Africa & 33.76 & 33.95 & 34.55 & 34.54 \\
\hline Cambodia & 52.63 & 53.08 & 55.29 & 53.49 & Yemen & 32.70 & 34.29 & 35.49 & 34.17 \\
\hline Egypt & 48.34 & 54.02 & 55.18 & 53.23 & Kazakhstan & 34.63 & 32.81 & 32.94 & 33.21 \\
\hline Tanzania & 51.89 & 51.89 & 54.26 & 53.05 & Uzbekistan & 29.12 & 31.12 & 32.24 & 30.81 \\
\hline Sri Lanka & 49.73 & 53.14 & 55.72 & 52.98 & Iraq & 25.58 & 25.93 & 25.32 & 25.52 \\
\hline Jamaica & 51.97 & 53.01 & 54.36 & 52.84 & & & & & \\
\hline & & & & & & & &
\end{tabular}

\section{〈Appendix 3〉 The Results by Individual industry (Fixed Effect Model)}

〈Table A3. 1〉 The Effects on the Korean Exports

\begin{tabular}{|c|c|c|c|c|c|c|c|c|}
\hline Variable & SITC 251 & SITC 334 & SITC 515 & SITC 516 & SITC 524 & SITC 525 & SITC 562 & SITC 598 \\
\hline $\mathrm{C}$ & $\begin{array}{l}22.308 \\
(0.697)\end{array}$ & $\begin{array}{c}-101.984 * * * \\
(-8.193) \\
\end{array}$ & $\begin{array}{c}-2.794 \\
(-0.461)\end{array}$ & \begin{tabular}{|c|}
$-60.936 * * *$ \\
$(-8.393)$ \\
\end{tabular} & $\begin{array}{c}-21.165 * * \\
(-2.185)\end{array}$ & $\begin{array}{l}-20.511 \\
(-0.710) \\
\end{array}$ & $\begin{array}{c}-60.137 * * * \\
(-3.299) \\
\end{array}$ & $\begin{array}{c}-55.243 * * * \\
(-11.230) \\
\end{array}$ \\
\hline $\ln (\mathrm{KGDP})$ & $\begin{array}{c}5.455 \\
(1.180) \\
\end{array}$ & $\begin{array}{c}8.007 * * * \\
(5.402) \\
\end{array}$ & $\begin{array}{l}1.424 * \\
(1.862)\end{array}$ & $\begin{array}{c}3.038 * * * \\
(3.393) \\
\end{array}$ & $\begin{array}{c}4.417 * * * \\
(3.877)\end{array}$ & $\begin{array}{c}5.113 \\
(1.615) \\
\end{array}$ & $\begin{array}{c}9.615^{* * * *} \\
(3.019)\end{array}$ & $\begin{array}{c}4.861 * * * \\
(8.761)\end{array}$ \\
\hline $\ln (\mathrm{GDP})$ & $\begin{array}{c}1.027 \\
(0.421) \\
\end{array}$ & $\begin{array}{c}0.252 \\
(0.262) \\
\end{array}$ & $\begin{array}{c}0.195 \\
(0.353) \\
\end{array}$ & $\begin{array}{l}1.469 * * \\
(2.367)\end{array}$ & $\begin{array}{c}-0.356 \\
(-0.419) \\
\end{array}$ & $\begin{array}{c}3.037 \\
(1.089) \\
\end{array}$ & $\begin{array}{c}-3.823 * * \\
(-2.341)\end{array}$ & $\begin{array}{c}1.692 * * * \\
(4.537)\end{array}$ \\
\hline $\ln (\mathrm{EPI})$ & $\begin{array}{c}-34.913^{* *} \\
(-2.556)\end{array}$ & $\begin{array}{c}0.790 \\
(0.188)\end{array}$ & $\begin{array}{c}-0.648 \\
(-0.301)\end{array}$ & $\begin{array}{c}3.231 \\
(1.243)\end{array}$ & $\begin{array}{c}-4.799 \\
(-1.390)\end{array}$ & $\begin{array}{c}-17.372 * \\
(-1.711)\end{array}$ & $\begin{array}{c}-2.955 \\
(-0.365)\end{array}$ & $\begin{array}{c}-4.181 * * \\
(-2.403)\end{array}$ \\
\hline EPIDUM & $\begin{array}{l}1.681 * \\
(1.898) \\
\end{array}$ & $\begin{array}{c}-0.187 \\
(-0.412) \\
\end{array}$ & $\begin{array}{c}-0.032 \\
(-0.145) \\
\end{array}$ & $\begin{array}{c}0.411 \\
(1.479) \\
\end{array}$ & $\begin{array}{c}0.097 \\
(0.261) \\
\end{array}$ & $\begin{array}{l}1.369^{*} \\
(1.856) \\
\end{array}$ & $\begin{array}{c}-0.540 \\
(-0.808) \\
\end{array}$ & $\begin{array}{c}0.168 \\
(0.949) \\
\end{array}$ \\
\hline FTA & $\begin{array}{c}0.787 \\
(1.001) \\
\end{array}$ & $\begin{array}{c}-0.029 \\
(-0.054) \\
\end{array}$ & $\begin{array}{c}-0.656 * * * \\
(-2.615)\end{array}$ & $\begin{array}{c}-0.130 \\
(-0.442) \\
\end{array}$ & $\begin{array}{c}-0.098 \\
(-0.275) \\
\end{array}$ & $\begin{array}{c}0.319 \\
(0.500) \\
\end{array}$ & $\begin{array}{c}0.093 \\
(0.165) \\
\end{array}$ & $\begin{array}{c}-0.296 \\
(-1.333) \\
\end{array}$ \\
\hline $\ln (\mathrm{DPGDP})$ & $\begin{array}{l}3.877 * * \\
(2.242)\end{array}$ & $\begin{array}{c}0.036 \\
(0.084)\end{array}$ & $\begin{array}{c}-0.370 * * \\
(-2.006)\end{array}$ & $\begin{array}{c}0.107 \\
(0.483)\end{array}$ & $\begin{array}{c}-0.433 \\
(-1.455)\end{array}$ & $\begin{array}{c}-1.115 \\
(-0.378)\end{array}$ & $\begin{array}{c}-0.056 \\
(-0.075)\end{array}$ & $\begin{array}{c}-0.056 \\
(-0.346)\end{array}$ \\
\hline Obsertion & 151 & 821 & 805 & 673 & 523 & 189 & 263 & 1215 \\
\hline $\begin{array}{l}\text { Country } \\
\text { Pairs }\end{array}$ & 39 & 107 & 101 & 95 & 82 & 39 & 60 & 120 \\
\hline Adj $R^{2}$ & 0.639 & 0.725 & 0.821 & 0.798 & 0.756 & 0.571 & 0.776 & 0.852 \\
\hline H-T $\chi^{2}(6)$ & $29.174 * * *$ & $22.340 * * *$ & $16.298 * *$ & $12.961 * *$ & $26.958 * * *$ & $14.589^{* *}$ & 9.010 & $48.932 * * *$ \\
\hline
\end{tabular}


Environmental Regulations and Korean Trades

\begin{tabular}{|c|c|c|c|c|c|c|c|c|}
\hline Variable & SITC 634 & SITC 635 & SITC 641 & SITC 642 & SITC 661 & SITC 67 & SITC 68 & SITC 69 \\
\hline $\mathrm{C}$ & $\begin{array}{c}4.281 \\
(0.334)\end{array}$ & $\begin{array}{c}17.221 * \\
(1.692)\end{array}$ & $\begin{array}{c}-56.558^{* * *} \\
(-9.462)\end{array}$ & $\begin{array}{c}-2.473 \\
(-0.423)\end{array}$ & $\begin{array}{c}6.389 \\
(0.439) \\
\end{array}$ & $\begin{array}{c}-60.727 * * * \\
(-11.548)\end{array}$ & $\begin{array}{c}-35.181 * * * \\
(-5.330)\end{array}$ & $\begin{array}{c}-28.326^{* * * *} \\
(-7.223)\end{array}$ \\
\hline $\ln (\mathrm{KGDP})$ & $\begin{array}{c}1.450 \\
(0.931)\end{array}$ & $\begin{array}{c}-3.070^{* * *} \\
(-2.665) \\
\end{array}$ & $\begin{array}{c}4.140 * * * \\
(6.073)\end{array}$ & $\begin{array}{c}-0.188 \\
(-0.289) \\
\end{array}$ & $\begin{array}{c}-1.988 \\
(-1.193) \\
\end{array}$ & $\begin{array}{c}5.217 * * * \\
(9.347) \\
\end{array}$ & $\begin{array}{c}2.561^{* * *} \\
(3.428) \\
\end{array}$ & $\begin{array}{c}2.146 * * * \\
(5.175) \\
\end{array}$ \\
\hline $\ln (\mathrm{GDP})$ & $\begin{array}{c}0.578 \\
(0.543) \\
\end{array}$ & $\begin{array}{c}3.820 * * * \\
(4.570) \\
\end{array}$ & $\begin{array}{c}0.983 * * \\
(2.107) \\
\end{array}$ & $\begin{array}{c}2.001^{* * *} \\
(4.629) \\
\end{array}$ & $\begin{array}{c}3.943 * * * \\
(3.585) \\
\end{array}$ & $\begin{array}{c}1.436^{* * * *} \\
(3.832) \\
\end{array}$ & $\begin{array}{c}1.827^{* * *} \\
(3.625) \\
\end{array}$ & $\begin{array}{c}2.235^{* * *} \\
(7.985) \\
\end{array}$ \\
\hline $\ln (\mathrm{EPI})$ & $\begin{array}{l}-7.182^{*} \\
(-1.760) \\
\end{array}$ & $\begin{array}{c}0.312 \\
(0.091) \\
\end{array}$ & $\begin{array}{c}-0.672 \\
(-0.322) \\
\end{array}$ & $\begin{array}{c}-0.260 \\
(-0.129) \\
\end{array}$ & $\begin{array}{c}-5.516 \\
(-1.165) \\
\end{array}$ & $\begin{array}{c}-3.588^{* *} \\
(-1.990) \\
\end{array}$ & $\begin{array}{c}-2.307 \\
(-1.018) \\
\end{array}$ & \begin{tabular}{|c}
$-2.909^{* * *}$ \\
$(-2.189)$ \\
\end{tabular} \\
\hline EPIDUM & $\begin{array}{c}-0.128 \\
(-0.259) \\
\end{array}$ & $\begin{array}{c}-0.331 \\
(-0.795)\end{array}$ & $\begin{array}{c}0.442 * * \\
(2.067) \\
\end{array}$ & $\begin{array}{c}-0.008 \\
(-0.038)\end{array}$ & $\begin{array}{c}-0.003 \\
(-0.006)\end{array}$ & $\begin{array}{c}-0.169 \\
(-0.866) \\
\end{array}$ & $\begin{array}{c}-0.086 \\
(-0.353)\end{array}$ & $\begin{array}{c}0.343^{* *} \\
(2.381) \\
\end{array}$ \\
\hline FTA & $\begin{array}{c}0.233 \\
(0.491)\end{array}$ & $\begin{array}{c}0.138 \\
(0.366)\end{array}$ & $\begin{array}{c}-0.666^{* *} \\
(-2.521) \\
\end{array}$ & $\begin{array}{c}-0.346 \\
(-1.304)\end{array}$ & $\begin{array}{c}0.194 \\
(0.348)\end{array}$ & $\begin{array}{c}-0.287 \\
(-1.210)\end{array}$ & $\begin{array}{c}-0.187 \\
(-0.642)\end{array}$ & $\begin{array}{c}-0.004 \\
(-0.023)\end{array}$ \\
\hline $\ln (\mathrm{DPGDP})$ & $\begin{array}{c}0.838 \\
(1.540) \\
\end{array}$ & $\begin{array}{c}-1.199 * * * \\
(-2.999) \\
\end{array}$ & $\begin{array}{c}0.527 * * * \\
(2.765) \\
\end{array}$ & $\begin{array}{l}-0.483 * * \\
(-2.454) \\
\end{array}$ & $\begin{array}{c}0.798 \\
(1.076) \\
\end{array}$ & $\begin{array}{l}0.353 * * \\
(2.015) \\
\end{array}$ & $\begin{array}{c}0.251 \\
(1.193) \\
\end{array}$ & $\begin{array}{c}0.082 \\
(0.619) \\
\end{array}$ \\
\hline Obsertion & 470 & 695 & 1165 & 1209 & 582 & 1222 & 1106 & 1306 \\
\hline $\begin{array}{l}\text { Country } \\
\text { Pairs }\end{array}$ & 87 & 111 & 119 & 120 & 103 & 120 & 120 & 120 \\
\hline Adj $R^{2}$ & 0.585 & 0.657 & 0.813 & 0.776 & 0.586 & 0.854 & 0.828 & 0.885 \\
\hline H-T $\chi^{2}(6)$ & $16.374 * *$ & $24.786 * * *$ & $11.204 * *$ & $36.552 * * *$ & $23.904 * * *$ & $16.467 * *$ & $13.652 * *$ & $29.083 * * *$ \\
\hline
\end{tabular}

( ) $\mathrm{t}$-value, $* \mathrm{p}<0.1, * * \mathrm{p}<0.05, * * * \mathrm{p}<0.01$

〈Table A3. 2〉 The effect on the Trade Flows

\begin{tabular}{|c|c|c|c|c|c|c|c|c|}
\hline Variable & SITC 251 & SITC 334 & SITC 515 & SITC 516 & SITC 524 & SITC 525 & SITC 562 & SITC 598 \\
\hline $\mathrm{C}$ & $\begin{array}{c}-21.078 * \\
(-1.876)\end{array}$ & $\begin{array}{c}-68.566^{* * *} \\
(-6.233) \\
\end{array}$ & $\begin{array}{c}8.024 \\
(1.230) \\
\end{array}$ & $\begin{array}{c}-45.507 * * * \\
(-7.434)\end{array}$ & $\begin{array}{c}-4.996 \\
(-0.707) \\
\end{array}$ & $\begin{array}{l}-19.130 \\
(-1.220)\end{array}$ & $\begin{array}{l}-20.537 \\
(-1.452)\end{array}$ & $\begin{array}{c}-48.968 * * * \\
(-10.445)\end{array}$ \\
\hline $\ln (\mathrm{KGDP})$ & $\begin{array}{c}3.971 * * * \\
(3.372)\end{array}$ & $\begin{array}{c}7.619 * * * \\
(6.047)\end{array}$ & $\begin{array}{l}1.338^{*} \\
(1.654)\end{array}$ & $\begin{array}{c}2.070 * * * \\
(2.814)\end{array}$ & $\begin{array}{c}3.397 * * * \\
(4.068)\end{array}$ & $\begin{array}{c}5.086^{* * *} \\
(3.145)\end{array}$ & $\begin{array}{c}-0.135 \\
(-0.090)\end{array}$ & $\begin{array}{c}3.702 * * * \\
(6.998)\end{array}$ \\
\hline $\ln (\mathrm{GDP})$ & $\begin{array}{l}1.775^{*} \\
(1.897)\end{array}$ & $\begin{array}{c}-0.688 \\
(-0.818)\end{array}$ & $\begin{array}{c}-0.819 \\
(-1.381)\end{array}$ & $\begin{array}{c}1.699 * * * \\
(3.224)\end{array}$ & $\begin{array}{c}-0.506 \\
(-0.794)\end{array}$ & $\begin{array}{c}-1.020 \\
(-0.743)\end{array}$ & $\begin{array}{l}1.830^{*} \\
(1.762)\end{array}$ & $\begin{array}{c}2.224 * * * \\
(6.194)\end{array}$ \\
\hline $\ln (\mathrm{EPI})$ & $\begin{array}{c}-10.205 * * * \\
(-2.876)\end{array}$ & $\begin{array}{c}-3.500 \\
(-0.934)\end{array}$ & $\begin{array}{c}0.510 \\
(0.218)\end{array}$ & $\begin{array}{c}1.609 \\
(0.735)\end{array}$ & $\begin{array}{c}-5.126 * * \\
(-2.123)\end{array}$ & $\begin{array}{l}-7.982 * \\
(-1.729)\end{array}$ & $\begin{array}{c}4.567 \\
(1.010)\end{array}$ & $\begin{array}{c}-3.329 * * \\
(-1.998)\end{array}$ \\
\hline EPIDUM & $\begin{array}{c}0.267 \\
(0.716)\end{array}$ & $\begin{array}{c}-0.036 \\
(-0.091)\end{array}$ & $\begin{array}{c}0.042 \\
(0.171)\end{array}$ & $\begin{array}{c}0.611 * * * \\
(2.627)\end{array}$ & $\begin{array}{c}-0.419 \\
(-1.480)\end{array}$ & $\begin{array}{l}1.124 * * \\
(2.421)\end{array}$ & $\begin{array}{c}-0.308 \\
(-0.640)\end{array}$ & $\begin{array}{c}0.208 \\
(1.241)\end{array}$ \\
\hline FTA & $\begin{array}{c}-0.373 \\
(-1.028)\end{array}$ & $\begin{array}{c}0.231 \\
(0.495)\end{array}$ & $\begin{array}{c}-0.161 \\
(-0.597)\end{array}$ & $\begin{array}{c}0.074 \\
(0.307)\end{array}$ & $\begin{array}{c}0.248 \\
(0.906)\end{array}$ & $\begin{array}{c}0.564 \\
(1.181)\end{array}$ & $\begin{array}{c}0.375 \\
(0.814)\end{array}$ & $\begin{array}{c}-0.106 \\
(-0.505)\end{array}$ \\
\hline $\ln$ (DPGDP) & $\begin{array}{c}-0.067 \\
(-0.198)\end{array}$ & $\begin{array}{c}0.105 \\
(0.276)\end{array}$ & $\begin{array}{c}-0.561 * * * \\
(-2.722)\end{array}$ & $\begin{array}{l}0.328^{*} \\
(1.698)\end{array}$ & $\begin{array}{c}-0.239 \\
(-1.169)\end{array}$ & $\begin{array}{c}0.730 \\
(0.850)\end{array}$ & $\begin{array}{c}-0.548 \\
(-1.177)\end{array}$ & $\begin{array}{c}0.030 \\
(0.197)\end{array}$ \\
\hline Obsertion & 500 & 948 & 893 & 743 & 620 & 361 & 515 & 1242 \\
\hline $\begin{array}{l}\text { Country } \\
\text { Pairs }\end{array}$ & 79 & 114 & 105 & 100 & 93 & 56 & 79 & 120 \\
\hline Adj $R^{2}$ & 0.798 & 0.752 & 0.835 & 0.881 & 0.843 & 0.772 & 0.715 & 0.665 \\
\hline $\mathrm{H}-\mathrm{T} \chi^{2}(6)$ & $20.048^{* * *}$ & $22.135^{* * *}$ & $19.702 * * *$ & $13.750 * *$ & $26.383^{* * *}$ & $11.381^{*}$ & 5.142 & $39.783^{* * *}$ \\
\hline
\end{tabular}




\begin{tabular}{|c|c|c|c|c|c|c|c|c|}
\hline Variable & SITC 634 & SITC 635 & SITC 641 & SITC 642 & SITC 661 & SITC 67 & SITC 68 & SITC 69 \\
\hline $\mathrm{C}$ & $\begin{array}{c}15.727^{*} \\
(1.838)\end{array}$ & $\begin{array}{c}4.842 \\
(0.593)\end{array}$ & $\begin{array}{c}-57.738 * * * \\
(-10.041)\end{array}$ & $\begin{array}{c}-15.108^{* *} \\
(-2.576\end{array}$ & $\begin{array}{c}-5.160 \\
(-0.454) \\
\end{array}$ & $\begin{array}{c}-54.377 * * * \\
(-10.406)\end{array}$ & $\begin{array}{c}-32.778 * * * \\
(-5.055)\end{array}$ & $\begin{array}{c}-26.578 * * * \\
(-6.733)\end{array}$ \\
\hline $\ln ($ KGDP) & $\begin{array}{c}-0.127 \\
(-0.131)\end{array}$ & $\begin{array}{l}-1.523^{*} \\
(-1.682) \\
\end{array}$ & $\begin{array}{c}2.961 * * * \\
(4.527) \\
\end{array}$ & $\begin{array}{c}1.062 \\
(1.646) \\
\end{array}$ & $\begin{array}{c}-0.445 \\
(-0.351) \\
\end{array}$ & $\begin{array}{c}4.646 * * * \\
(8.369)\end{array}$ & $\begin{array}{c}2.355^{* * *} \\
(3.333) \\
\end{array}$ & $\begin{array}{c}2.234^{* * * *} \\
(5.375) \\
\end{array}$ \\
\hline $\ln (\mathrm{GDP})$ & $\begin{array}{l}1.193^{*} \\
(1.715) \\
\end{array}$ & $\begin{array}{c}2.599 * * * \\
(4.137) \\
\end{array}$ & $\begin{array}{c}1.500^{* * * *} \\
(3.327) \\
\end{array}$ & $\begin{array}{c}1.204 * * * \\
(2.780) \\
\end{array}$ & $\begin{array}{c}3.174 * * * \\
(3.657) \\
\end{array}$ & $\begin{array}{c}0.858^{* *} \\
(2.300) \\
\end{array}$ & $\begin{array}{c}1.795 * * * \\
(3.801) \\
\end{array}$ & $\begin{array}{c}2.291^{* * *} \\
(8.184) \\
\end{array}$ \\
\hline $\ln (\mathrm{EPI})$ & $\begin{array}{c}-4.542 \\
(-1.603) \\
\end{array}$ & $\begin{array}{c}0.114 \\
(0.039) \\
\end{array}$ & $\begin{array}{c}2.194 \\
(1.092) \\
\end{array}$ & $\begin{array}{c}-0.005 \\
(-0.002) \\
\end{array}$ & $\begin{array}{c}-4.066 \\
(-1.057) \\
\end{array}$ & $\begin{array}{c}-1.302 \\
(-0.725) \\
\end{array}$ & $\begin{array}{c}-2.314 \\
(-1.064) \\
\end{array}$ & $\begin{array}{c}-3.726^{* * *} \\
(-2.789) \\
\end{array}$ \\
\hline EPIDUM & $\begin{array}{c}0.301 \\
(0.959) \\
\end{array}$ & $\begin{array}{c}0.271 \\
(0.875) \\
\end{array}$ & $\begin{array}{c}0.406^{* *} \\
(1.974)\end{array}$ & $\begin{array}{c}0.214 \\
(0.985) \\
\end{array}$ & $\begin{array}{c}0.344 \\
(0.780) \\
\end{array}$ & $\begin{array}{c}-0.197 \\
(-1.009)\end{array}$ & $\begin{array}{l}-0.426^{*} \\
(-1.792) \\
\end{array}$ & $\begin{array}{c}0.299 * * \\
(2.064) \\
\end{array}$ \\
\hline FTA & $\begin{array}{c}-0.139 \\
(-0.436)\end{array}$ & $\begin{array}{c}-0.283 \\
(-0.840)\end{array}$ & $\begin{array}{l}-0.616^{* *} \\
(-2.422) \\
\end{array}$ & $\begin{array}{c}-0.18 \\
(-0.691)\end{array}$ & $\begin{array}{c}0.142 \\
(0.318)\end{array}$ & $\begin{array}{c}0.123 \\
(0.518)\end{array}$ & $\begin{array}{c}-0.054 \\
(-0.182)\end{array}$ & $\begin{array}{c}0.105 \\
(0.573)\end{array}$ \\
\hline $\ln (\mathrm{DPGDP})$ & $\begin{array}{c}0.272 \\
(0.946) \\
\end{array}$ & $\begin{array}{c}-0.421 \\
(-1.504) \\
\end{array}$ & $\begin{array}{c}0.591 * * * \\
(3.201) \\
\end{array}$ & $\begin{array}{c}-0.098 \\
(-0.501) \\
\end{array}$ & $\begin{array}{c}0.284 \\
(0.719) \\
\end{array}$ & $\begin{array}{c}0.280 \\
(1.597) \\
\end{array}$ & $\begin{array}{l}0.489 * * \\
(2.287) \\
\end{array}$ & $\begin{array}{c}0.071 \\
(0.531) \\
\end{array}$ \\
\hline Obsertion & 748 & 823 & 1185 & 1227 & 773 & 1241 & 1163 & 1309 \\
\hline $\begin{array}{l}\text { Country } \\
\text { Pairs }\end{array}$ & 107 & 115 & 119 & 120 & 112 & 120 & 120 & 120 \\
\hline Adj $R^{2}$ & 0.791 & 0.767 & 0.837 & 0.809 & 0.623 & 0.863 & 0.839 & 0.891 \\
\hline $\begin{array}{c}\mathrm{H}-\mathrm{T} \\
\chi^{2}(6)\end{array}$ & $14.189 * *$ & $18.019 * * *$ & $15.899 * *$ & $20.625 * * *$ & $16.259 * *$ & $13.245^{* *}$ & $15.360^{* *}$ & $27.597 * * *$ \\
\hline
\end{tabular}

( ) t-value, ${ }^{*} \mathrm{p}<0.1,{ }^{* *} \mathrm{p}<0.05,{ }^{* * *} \mathrm{p}<0.01$

〈Table A3. 3〉 The Effects on the Korean International competitiveness (Export/Import)

\begin{tabular}{c|c|c|c|c|c|c|c|c}
\hline Variable & SITC 251 & SITC 334 & SITC 515 & SITC 516 & SITC 524 & SITC 525 & SITC 562 & SITC 598 \\
\hline $\mathrm{C}$ & $\begin{array}{c}4.640 \\
(1.328)\end{array}$ & $\begin{array}{c}0.334 \\
(0.141)\end{array}$ & $\begin{array}{c}3.703^{* * *} \\
(2.792)\end{array}$ & $\begin{array}{c}-0.973 \\
(-1.033)\end{array}$ & $\begin{array}{c}1.099 \\
(1.261)\end{array}$ & $\begin{array}{c}-5.000 \\
(-1.140)\end{array}$ & $\begin{array}{c}-3.656^{*} \\
(-1.823)\end{array}$ & $\begin{array}{c}4.209^{* *} \\
(2.274)\end{array}$ \\
\hline $\begin{array}{c}\ln (\mathrm{KGDP} / \\
\text { GDP })\end{array}$ & $\begin{array}{c}3.526 \\
(0.649)\end{array}$ & $\begin{array}{c}-6.372^{* * *} \\
(-3.046)\end{array}$ & $\begin{array}{c}-7.221^{* * *} \\
(-3.531)\end{array}$ & $\begin{array}{c}1.762 \\
(0.762)\end{array}$ & $\begin{array}{c}-13.453^{* * *} \\
(-2.849)\end{array}$ & $\begin{array}{c}-3.664 \\
(-0.293)\end{array}$ & $\begin{array}{c}-3.973 \\
(-0.999)\end{array}$ & $\begin{array}{c}-1.569 \\
(-1.085)\end{array}$ \\
\hline $\ln (\mathrm{EPI} / \mathrm{KEPI})$ & $\begin{array}{c}-2.236 \\
(-0.160)\end{array}$ & $\begin{array}{c}-5.532 \\
(-0.897)\end{array}$ & $\begin{array}{c}-6.369^{* *} \\
(-1.995)\end{array}$ & $\begin{array}{c}-10.189^{* * *} \\
(-2.737)\end{array}$ & $\begin{array}{c}-3.791 \\
(-0.726)\end{array}$ & $\begin{array}{c}-22.233^{* *} \\
(-2.219)\end{array}$ & $\begin{array}{c}-3.919 \\
(-0.374)\end{array}$ & $\begin{array}{c}-8.237^{* * *} \\
(-2.858)\end{array}$ \\
\hline $\begin{array}{c}\ln (\mathrm{KPGD} / \\
\text { PGDP) }\end{array}$ & $\begin{array}{c}-10.471^{* *} \\
(-2.174)\end{array}$ & $\begin{array}{c}9.015^{* * *} \\
(4.353)\end{array}$ & $\begin{array}{c}6.575^{* * *} \\
(3.620)\end{array}$ & $\begin{array}{c}-1.366 \\
(-0.661)\end{array}$ & $\begin{array}{c}15.685 * * * \\
(3.401)\end{array}$ & $\begin{array}{c}-1.787 \\
(-0.140)\end{array}$ & $\begin{array}{c}7.141^{* *} \\
(2.166)\end{array}$ & $\begin{array}{c}-0.076 \\
(-0.058)\end{array}$ \\
\hline Obsertion & 110 & 482 & 465 & 390 & 287 & 115 & 161 & 754 \\
\hline $\begin{array}{c}\text { Country } \\
\text { Pairs }\end{array}$ & 27 & 85 & 64 & 60 & 44 & 21 & 38 & 112 \\
\hline Adj R $\mathrm{R}^{2}$ & 0.717 & 0.677 & 0.727 & 0.736 & 0.723 & 0.733 & 0.805 & 0.773 \\
\hline H-Test $\chi^{2}(6)$ & $12.932^{* * *}$ & $21.009^{* * *}$ & $15.544^{* * * *}$ & 1.331 & $16.547 * * *$ & $16.019^{* * *}$ & 5.527 & $11.335^{* *}$ \\
\hline
\end{tabular}


Environmental Regulations and Korean Trades

\begin{tabular}{|c|c|c|c|c|c|c|c|c|}
\hline Variable & SITC 634 & SITC 635 & SITC 641 & SITC 642 & SITC 661 & SITC 67 & SITC 68 & SITC 69 \\
\hline $\mathrm{C}$ & $\begin{array}{c}-5.109 * * * \\
(-3.595)\end{array}$ & $\begin{array}{c}6.048 * * * \\
(3.618)\end{array}$ & $\begin{array}{c}-2.275 \\
(-1.432)\end{array}$ & $\begin{array}{c}4.638 * * \\
(2.554)\end{array}$ & $\begin{array}{c}-1.435 \\
(-0.891)\end{array}$ & $\begin{array}{c}1.415 \\
(0.840)\end{array}$ & $\begin{array}{l}-3.851 * \\
(-1.955)\end{array}$ & $\begin{array}{c}3.442 * * \\
(2.099)\end{array}$ \\
\hline $\begin{array}{c}\ln (\mathrm{KGDP} / \\
\text { GDP })\end{array}$ & $\begin{array}{c}-1.874 \\
(-0.388)\end{array}$ & $\begin{array}{c}-8.771 * * * \\
(-4.153)\end{array}$ & $\begin{array}{c}5.797 * * * \\
(3.062)\end{array}$ & $\begin{array}{c}-1.184 \\
(-0.774)\end{array}$ & $\begin{array}{c}-0.900 \\
(-0.223)\end{array}$ & $\begin{array}{c}2.125 \\
(1.570)\end{array}$ & $\begin{array}{l}3.144 * \\
(1.861)\end{array}$ & $\begin{array}{c}-0.462 \\
(-0.463)\end{array}$ \\
\hline $\begin{array}{c}\ln (\mathrm{EPI} / \\
\mathrm{KEPI})\end{array}$ & $\begin{array}{c}-6.569 \\
(-1.283)\end{array}$ & $\begin{array}{c}2.398 \\
(0.594)\end{array}$ & $\begin{array}{c}-4.284 \\
(-1.240)\end{array}$ & $\begin{array}{c}5.492 \\
(1.611)\end{array}$ & $\begin{array}{c}-23.986 * * * \\
(-3.980)\end{array}$ & $\begin{array}{c}-9.526^{* * *} \\
(-3.119)\end{array}$ & $\begin{array}{c}-3.163 \\
(-0.987)\end{array}$ & $\begin{array}{c}0.842 \\
(0.352)\end{array}$ \\
\hline $\begin{array}{c}\ln (\mathrm{KPGD} / \\
\text { PGDP) }\end{array}$ & $\begin{array}{c}3.978 \\
(0.829)\end{array}$ & $\begin{array}{c}5.952 * * * \\
(2.989)\end{array}$ & $\begin{array}{c}-4.832 * * * \\
(-2.932)\end{array}$ & $\begin{array}{c}-0.529 \\
(-0.370)\end{array}$ & $\begin{array}{c}-0.348 \\
(-0.090)\end{array}$ & $\begin{array}{c}-4.481 * * * \\
(-3.476)\end{array}$ & $\begin{array}{c}-2.485 \\
(-1.620)\end{array}$ & $\begin{array}{c}0.744 \\
(0.752)\end{array}$ \\
\hline Obsertion & 290 & 493 & 546 & 696 & 330 & 731 & 737 & 1029 \\
\hline $\begin{array}{c}\text { Country } \\
\text { Pairs }\end{array}$ & 53 & 76 & 80 & 100 & 56 & 98 & 103 & 118 \\
\hline Adj $R^{2}$ & 0.705 & 0.582 & 0.810 & 0.675 & 0.687 & 0.746 & 0.672 & 0.671 \\
\hline H-Test $\chi^{2}(6)$ & 3.995 & $22.121 * * *$ & $12.647 * * *$ & $16.608 * * *$ & $8.880 * *$ & $18.360 * * *$ & 3.952 & 5.183 \\
\hline
\end{tabular}

( ) t-value, * ${ }^{*}<0.1, * * \mathrm{p}<0.05, * * * \mathrm{p}<0.01$ 